\title{
THE WEALTH MOBILITY OF MEN AND WOMEN DURING THE 1960s AND 1970s
}

\author{
BY RichaRd H. STECKEL* \\ Ohio State University, Columbus and National Bureau of Economic Research \\ AND \\ JAYANTHI KRISHNAN \\ Temple University, Philadelphia
}

\begin{abstract}
Research on poverty and inequality is dominated by cross-section studies that are useful but disguise change over time. Investigation of change requires longitudinal data, which are relatively rare and expensive. This paper researches wealth mobility in a national sample of 4,255 households monitored in the National Longitudinal Surveys of Older Men and of Mature Women from the mid-1960s to the mid-1970s. Our measure of wealth is net family assets, excluding automobiles. We present descriptive measures and estimate econometric models of mobility, including persistence in the lower and the upper end of the wealth distribution, and movement into the upper and the lower end of the wealth distribution. The results place inequality measures in perspective and shed light on mechanisms that influence household wealth mobility. The gainers were farmers and those with skilled jobs or high levels of education, while groups that fell behind included single people, blacks, and families disrupted by divorce or death of a spouse.
\end{abstract}

\section{INTRODUCTION}

Study of inequality in the United States has intensified with the debate on the effectiveness of social and economic policy during the 1980s and 1990s. Economists noting rising poverty rates and growing inequality have implicated factors such as international trade, biased technological change, shifts in product demand, the demise of unions, and a decline in the real value of the minimum wage (Blackburn et al., 1990/91; Bound and Johnson, 1992; Hanratty and Blank, 1992; Katz and Murphy, 1992; Welch, 2001). Policy analysts have debated the efficacy of affirmative action, tax policies, the welfare system, and other programs on inequality and poverty in the past two decades (Murray, 1984; Wilson, 1987; Jencks, 1992).

Although more research on inequality and its causes and remedies is needed, we suggest that the debate has given insufficient attention to economic mobility. ${ }^{1}$ Cross-section measures are widely used to chart differences and trends, but give no

Note: We thank Ngina Chiteji, Nancy Jianakoplos, Stanley Lebergott, Robert Margo, Pat Rhoton, Thomas Weiss, Jay Zagorsky, two referees, and seminar participants at Miami (Ohio), Vanderbilt, NBER, and the Levy Economics Institute for comments, suggestions or other help.

*Correspondence to: Richard H. Steckel, Economics Department, Ohio State University, Columbus, Ohio 43210, USA (steckel.1@osu.edu).

${ }^{1}$ Here we mean mobility broadly construed. Much effort has been devoted recently to questions dealing with persistence in poverty.

(C) 2006 The Authors

Journal compilation (C) 2006 International Association for Research in Income and Wealth Published by Blackwell Publishing, 9600 Garsington Road, Oxford OX4 2DQ, UK and 350 Main St, Malden, MA, 02148, USA. 
insights into temporal processes that affect particular individuals. Economic mobility is relatively uninteresting in circumstances of near equality measured cross-sectionally: each person has approximately the same claim on resources over time. Yet, the degree of economic mobility clearly influences one's interpretation of cross-section measures in an environment of high or growing inequality. ${ }^{2}$ It is important to know, for example, whether the poor or the rich were entrenched and whether opportunities were realized for upward or downward movement.

Research on mobility has been modest compared with needs in the area principally because the longitudinal data required are difficult and expensive to collect. Some income mobility research has been conducted for the modern period (see, for example, Duncan and Hoffman, 1981; Shorrocks, 1981; Duncan, 1984), and a handful of wealth mobility studies have been done for the United States in the nineteenth or twentieth centuries (see Kearl and Pope, 1984; Steckel, 1990; Jianakoplos and Menchik, 1997; Herscovici, 1998).

Because economic opportunities vary with the patterns of economic growth, it is valuable to catalogue and analyze mobility under a wide variety of conditions. This paper includes an era when growth was very rapid (the 1960s and early 1970s), but the study window does embrace an episode of very slow growth after 1973. The time period also covers a large increase in the supply of well-educated workers. In one sense, our paper might be considered a historical study because the time period precedes the current focus on inequality research in the 1980s and 1990s. Whatever the precise definition of historical, our research provides valuable chronological perspective on more recent events of considerable interest.

Here we investigate wealth mobility in a national sample of 4,255 households monitored in the National Longitudinal Survey (NLS) of Older Men and of Mature Women. ${ }^{3}$ We present descriptive measures and estimate econometric models of mobility, including persistence in the lower and the upper end of the wealth distribution, and movement into the upper and the lower end of the wealth distribution. The results place inequality measures in perspective and shed light on mechanisms that influence household wealth mobility. Relative winners over the period included farmers and those with skilled jobs or high levels of education, while groups that fell behind included single people, blacks, and families disrupted by divorce or death of a spouse.

\section{The DAta}

Our database, which we constructed by pooling, contains 4,255 households from the NLS, 2,237 households from the survey of Older Men and 2,018

\footnotetext{
${ }^{2}$ Wealth inequality in the United States is moderately high compared with other industrial countries. In the early 1970 s the percentage of wealth held by the top 1 percent of the population was about 26.4 in the U.S. compared with 19 in France, 19.6 in Canada, 23 in Sweden, 25 in Denmark, 28 in Belgium, and 31.5 in the UK (see findings reported in Wolff, 1987).

${ }^{3}$ Although both surveys were designed to represent the civilian non-institutionalized population, they also contain over samples of nonwhites, for which we adjust.
} 
households from the survey of Mature Women. ${ }^{4}$ While our approach is similar to Jianakopolos and Menchik (1997), we differ in assembling not only a much larger database but one that includes an age distribution more representative of the adult population (an important point given the sensitivity of wealth to age) and one that includes many households headed by women. The men interviewed in our sample were aged 45-59 in 1966, and the women interviewed were aged 30-44 in 1967. Although 76 percent of the households in our sample of mature women were headed by men in period 1 , the pooled database also provides information on the economic fortunes of households headed by women. We study these households over a ten-year time interval, beginning in 1966 for the men's sample and in 1967 for the women's sample.

Our measure of wealth is net family assets (excluding automobiles), converted to 1967 dollars using the Consumer Price Index. This asset variable includes equity in homes or farms, business assets, other property, and financial assets (savings accounts, bonds, stocks, and mutual funds) minus personal loans and other liabilities. ${ }^{5}$ Unfortunately, the measure does not include pension or annuity wealth. ${ }^{6}$ According to the NLS, net family assets is a "key" variable that is uniformly constructed across years and across samples of older men and mature women. We discuss the issues of non-response and selectivity in the Appendix, where we show that wealth in period 1 is not systematically related to non-response in period 2.

${ }^{4}$ The samples are described in Center for Human Resource Research (1991). Information on households common to both data sources was taken from the cohort of older men.

Although the pooled data set of older men and mature women has several advantages, it is important to consider the possibility of reporting biases. In particular, men and women may have had different information or perceptions of household assets. If women had less access to household financial data, they may have reported lower values of household wealth. We investigate this issue by comparing the responses of men and women in a pairs sample: husbands and wives in the same household who were interviewed by the NLS Men and NLS Women surveys, respectively. 1971 was the only year that husbands and wives in the pairs sample were asked identical wealth questions in the same year. A regression of household wealth in 1971 (converted to 1967 prices) as reported by women (ASSET71-W) on household wealth as reported by men (ASSET71-M) shows that the majority of married women underreported assets relative to their husbands (t-values are given in parentheses):

$$
\text { Asset71-M=2,460+0.926ASSET71-W, } \mathrm{R}^{2}=0.81, \mathrm{~N}=244
$$

$$
\text { (32.33) (2.99) }
$$

According to the equation, the relative extent of underreporting declined as wealth increased, and men and women reported equal amounts at $\$ 33,243$ in assets (approximately the 90th percentile of household wealth among these households). We used the estimated equation to convert wealth estimates as reported by women who were married in periods 1 or 2 into equivalent amounts as reported by husbands.

We omitted two households in which wealth values from the two data sources were grossly unequal. Inspection of a scatter diagram and a t-test on a quadratic term indicate that a linear equation adequately describes the data.

${ }^{5}$ Fortunately, top-coding is a minor problem in our sample. Only one household in each period was top-coded (asset value of more than $\$ 999,999$ ). We are aware that the wealthy may underreport assets, but note that if underreporting is reasonably consistent across time periods the phenomenon is less pressing for the study of mobility than for inequality. To the extent that the wealthy underreport relatively more assets than the poor, mobility will be understated.

${ }^{6}$ Results presented by Feldstein (1976) and by Wolff (1992) indicate that social security and pension wealth are substantially more equally distributed that other types of wealth. This result holds even in dual pension households (Jianakoplos and Bajtelsmit, 2002). Excluding this type of wealth increases measured inequality but has less effect on measured mobility. If social security and pension wealth were evenly distributed, for example, its exclusion would have no effect on measured mobility. 
TABLE 1

HouseHold WeALTH IN NLS SAMPLES ${ }^{\mathrm{a}}$

\begin{tabular}{lrccrr}
\hline \hline Group & Mean 1 & Mean 2 & Median $1^{\mathrm{b}}$ & Median 2 $^{\mathrm{c}}$ & $\mathrm{N}$ \\
\hline Pooled sample & 19,189 & 27,201 & 6,653 & 11,463 & 4,255 \\
Head 30-39 period 1 & 9,853 & 18,609 & 4,360 & 9,704 & 1,067 \\
Head 40-49 period 1 & 17,973 & 27,423 & 7,399 & 12,220 & 1,773 \\
Head 50-59 period 1 & 27,879 & 33,473 & 8,247 & 11,699 & 1,415 \\
NLSM & 25,910 & 33,385 & 8,247 & 12,714 & 2,237 \\
NLSW & 11,700 & 20,312 & 5,295 & 10,174 & 2,018 \\
NLSW-M & 12,967 & 22,418 & 7,566 & 13,229 & 1,529 \\
NLSW-W & 5,896 & 10,654 & 0 & 443 & 489 \\
\hline
\end{tabular}

Source: NLS samples of older men in 1966 and 1976, and of mature women in 1967 and 1977.

Notes: ${ }^{a}$ All figures are in 1967 dollars. The suffixes -M and -W denote households in the Mature Women sample headed by men and women, respectively.

${ }^{\mathrm{b}}$ Period 1.

'Period 2.

The largest non-response rates were for blacks and other ethnicities, but as indicated below we do adjust for sample/population differences in the proportion of these groups in each year.

We also made adjustments for ethnic composition and for age. The NLS surveys were designed to represent the civilian, non-institutionalized population but deliberately over-sampled black households (Center for Human Resource Research, 1991). Blacks comprise 31 percent of our sample but constituted only 9.45 percent of the households in the national population in 1970. To adjust for the over-representation of blacks in the NLS, we weighted households headed by blacks by their share in the national population. In making the ethnicity adjustment, we calculated the wealth distribution by first tabulating the number of people in the population represented by each household, from which we determined the proportion of the population represented by each household. We then ranked the households by wealth and assigned percentiles based on the cumulative sample weights. In ranking households by wealth, we followed Jianakoplos et al. (1989) by using all observations that reported net family assets in both periods $(\mathrm{N}=4,255)$.

Numerous studies establish a systematic relationship between age and wealth ownership, and for this reason the results on mobility in Section 6 are presented with and without adjustments for age. In cross-sections, wealth tends to follow a hump, increasing with age until individuals reach their 50 s or early 60 s, consistent with models of life-cycle savings. As Shorrocks (1975) has shown, however, the pattern could differ in longitudinal data, depending upon the balance of productivity effects across cohorts and of mortality rates that vary by level of wealth. Therefore the effect of age on mobility is an empirical matter. In a transition matrix, for example, someone aged 30 may or may not be more upwardly mobile than someone aged 50 or 60 . Thus the matrix itself could be a function of the age distribution of those studied.

Table 1 presents means and medians of household wealth in periods 1 and 2 for the pooled sample and various subgroups. In all categories, real wealth increased over the 10 year interval, and typical of wealth distributions reported 
elsewhere, the mean everywhere exceeded the median. The means and medians differ by data source, in part because the age distributions differ in the two subsamples. Household wealth levels were generally larger in the NLS men as opposed to the women, primarily because the typical head was older in the men's sample and because more household heads in the women's sample were single. These data display an age pattern of wealth similar to that found in other studies: accumulation was most rapid when individuals were in their 30 s and 40 s and slowed down or declined thereafter.

We place our data in historical perspective by noting that the middle of the twentieth century witnessed a decline in the share of wealth held, but not the share of income received, by the very rich. Estate data assembled by Wolff and Marley (1989, p. 786) indicate that the share of wealth held by the top 1 percent of the population declined by roughly 40 percent between 1965 and 1976, a result that is robust to alternative definitions of wealth. One may quarrel with their version of the estate tax multiplier method, but the amount is so large that the fact of an important decline seems well established. ${ }^{7}$ Using estate-data evidence, Smith (1984) also reports a decline of similar magnitude for the share of net worth held by the top 0.5 percent of individuals. Income shares of the rich, calculated from federal tax returns, were approximately stable during our sample period (Piketty and Saez, 2003).

The end points of our time periods were not marked by unusual cyclical phenomena, but the window does embrace subperiods of strong and weak growth. The unemployment rate was 3.8 percent in 1966 and 1967, 7.7 percent in 1976, and 7.0 percent in 1977 (Bureau of Labor Statistics, 1978). Growth rates were sluggish in the 1970s compared with the 1960s, and in the second period the economy was coping with rapidly rising oil prices. Based on the Penn World Tables, real per capita GDP growth was approximately 3.0 percent per year from the mid 1960s to 1973, and then was approximately zero from then to $1975-76$ (Heston et al., 2002). ${ }^{8}$

\section{Characteristics}

Table 2 presents information on the distribution of wealth in our database. The Gini coefficients range from 0.578 to 0.761 depending on the year and the region of the country. The top 1 percent of wealth holders had 0.118 to 0.197 of total wealth, and the proportion of households with zero or negative net family assets ranged from 0.084 to 0.185 . Inequality decreased over time, which is consistent with the aging of this group of households: younger people, who tend to be poor, accumulated wealth while older people, who tend to be wealthy, decumulated assets, prompted by retirement or by a decline of earnings that is typical at older ages of employment. The Gini coefficient was approximately 18 percent higher in the South compared with the rest of the country, a result similar to the regional difference that prevailed a little more than a century earlier (Steckel, 1990).

${ }^{7}$ See the comments by Robert B. Avery following the paper by Wolff and Marley.

${ }^{8}$ It would be interesting to study the effects of business cycles on wealth mobility. One might suspect that the mobility of the rich is pro-cyclical because they hold a large share of their wealth as financial assets. 
TABLE 2

Characteristics of the Distribution of Wealth

\begin{tabular}{|c|c|c|c|c|c|c|}
\hline & \multirow[b]{2}{*}{$\mathrm{N}$} & \multirow{2}{*}{$\begin{array}{l}\text { Proportion with } \\
\text { Zero or Less }\end{array}$} & \multicolumn{3}{|c|}{ Proportion of Wealth Held by } & \multirow[b]{2}{*}{ Gini } \\
\hline & & & Top $1 \%$ & Top 5\% & Top 20\% & \\
\hline \multicolumn{7}{|l|}{ Sample } \\
\hline Year 1 & 4,255 & 0.108 & 0.166 & 0.378 & 0.683 & 0.663 \\
\hline Year 2 & 4,255 & 0.101 & 0.118 & 0.314 & 0.621 & 0.603 \\
\hline \multicolumn{7}{|c|}{ Non-South } \\
\hline Year 1 & 2,608 & 0.084 & 0.157 & 0.357 & 0.660 & 0.639 \\
\hline Year 2 & 2,581 & 0.087 & 0.110 & 0.295 & 0.599 & 0.578 \\
\hline \multicolumn{7}{|l|}{ South } \\
\hline Year 1 & 1,646 & 0.163 & 0.197 & 0.438 & 0.738 & 0.715 \\
\hline Year 2 & 1,674 & 0.134 & 0.147 & 0.369 & 0.671 & 0.656 \\
\hline
\end{tabular}

Wealth was more equally distributed in our sample than in the mid-nineteenth century United States. In 1860 the Gini coefficient was 0.761 (Steckel, 1990), or 20 percent higher than the average for the two periods in these data. In 1860 the top 1 percent held 20.5 percent and the top 5 percent held 48.5 percent of the wealth, while the corresponding averages for the two periods in our sample are 16.6 percent and 37.8 percent.

\section{Mobility}

The extent of persistence and mobility across deciles of the wealth distribution is portrayed in Tables 3 and $4 .^{9}$ Traditionally, transition matrices are presented in raw form, i.e. unadjusted for age composition, which is the case in Table 3 . The first row of the table shows that 22.72 percent of those who were in the lowest decile in the first period remained there ten years later. Yet, most of those who left the lowest rung did not go very far; over 46 percent of those in the first decile in period 1 moved only to the second decile, and only 11.88 percent made it to the fifth decile or beyond. Similarly, of those in the second lowest decile in period 1, only 15.31 percent made it to the fifth decile or beyond. The table also shows that over 61 percent of the households in the top 10 percent of the distribution in period 1 remained in that position ten years later. Moreover, those who left the top of the distribution usually moved only a short distance; only 8.4 percent fell to the fifth decile or below, and just 1.69 percent fell to the bottom 20 percent of the distribution.

Table 3 also portrays average values of wealth within each decile, which show distance moved in monetary rather than percentile terms. The amounts might be compared with median family income in 1967, which was $\$ 7,933$ (U.S. Bureau of the Census, 1975). The absolute increases were small at the lower end, amounting

${ }^{9}$ The median levels of wealth within each decile (age unadjusted) were (in period 1): $(\$ 305)$; $\$ 150$; $\$ 2,740 ; \$ 5,206 ; \$ 7,731 ; \$ 10,484 ; \$ 14,144 ; \$ 19,647 ; \$ 30,410$; and $\$ 68,037$; and in period 2 were: $(\$ 223)$; $\$ 235 ; \$ 5,090 ; \$ 9,469 ; \$ 13,519 ; \$ 18,133 ; \$ 23,613 ; \$ 30,840 ; \$ 45,212$; and $\$ 92,513$. 


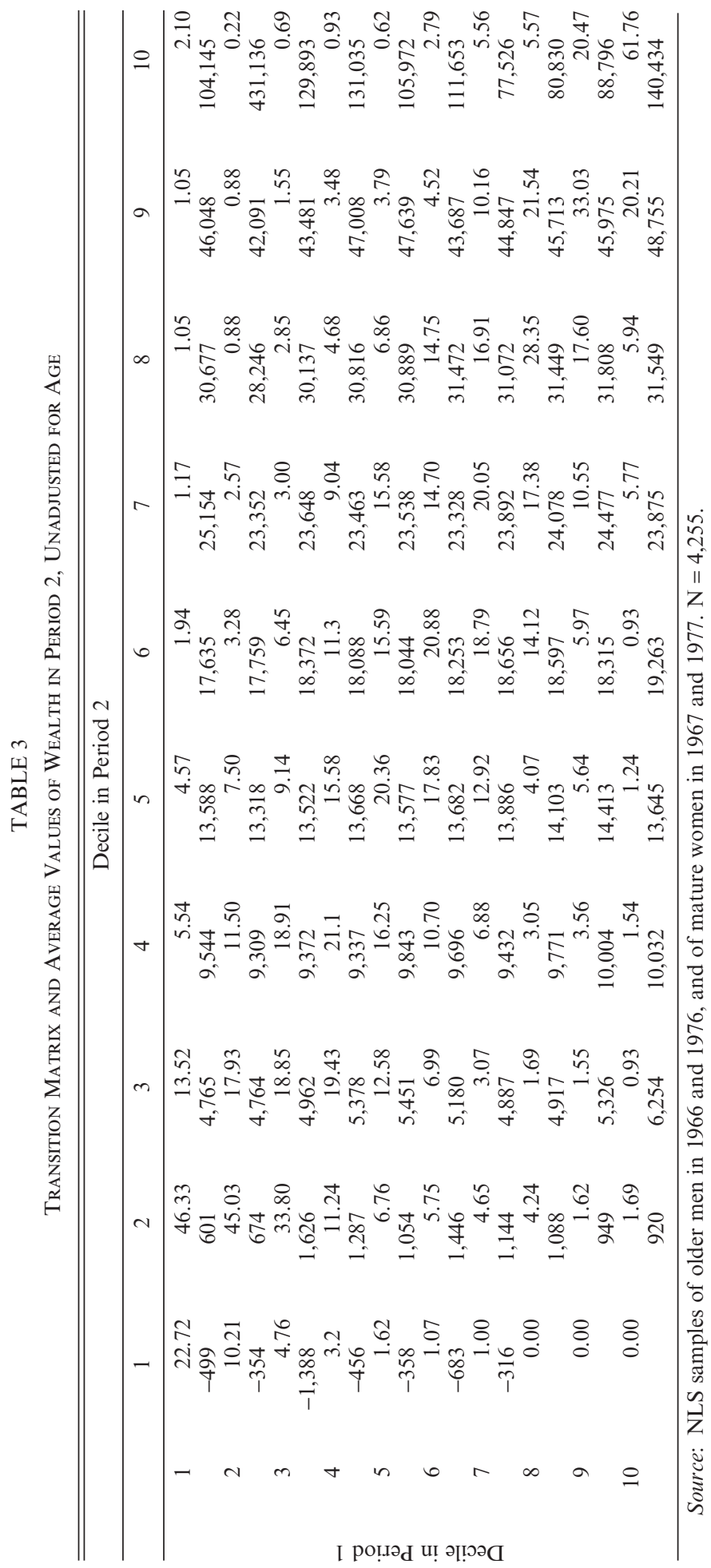




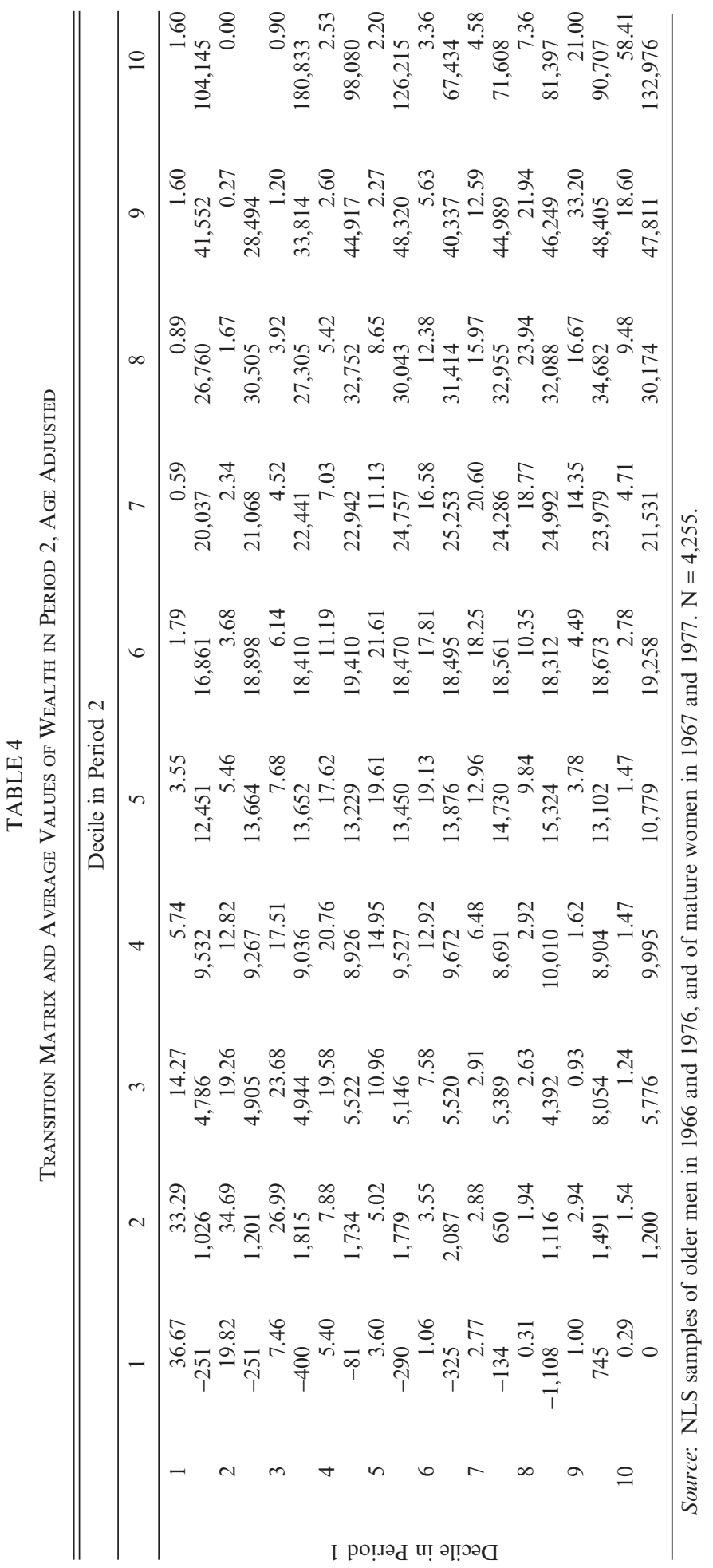


to $\$ 1,100$ ( $-\$ 499$ to $\$ 601$ ) for the transition from decile 1 to decile 2 among those who were in the first decile in period 1 . The amounts tended to increase by decile in period 2, and by far the largest gains occurred in the transition from the 9 th to the top decile. Among these, the greatest absolute increase was $\$ 91,679$ for those in the 10th decile in period 1 (if one ignores the very small sample size in row 2 , column 10 of the matrix).

While scholars recognize the influence of age on wealth, less has been done to adjust measures of mobility for its effects. Here we adjust by tabulating separate wealth distributions for each age cohort in each time period and then pooling the separate distributions to obtain wealth distributions for the entire group in each period. ${ }^{10}$ The procedure constructs 30 transition matrices, one for each cohort in the sample (ages 30-59 in period 1). Then, these 30 transition matrices are averaged together using weights equal to the proportions that each age group comprises in the entire U.S. population. In this way the mobility of an individual aged 30 is compared relative to that of others aged 30 , etc, and the overall wealth distributions and the mobility pattern are independent of the age distribution. Unless otherwise specified, results pertain to data unadjusted for age.

The relevance of age for mobility can be seen by comparing unadjusted with age-adjusted results. Persistence rates at the upper end are similar in both Table 3 and Table 4, but the age-adjusted data reveal somewhat greater downward mobility from the top. For example, in the age-adjusted data, 58.41 as opposed to 61.7 percent persisted in the top decile, and 6.01 percent versus 5.4 percent of those in the top fell to the bottom five deciles.

The age adjustments matter most for mobility near the bottom of the wealth distribution. In the age-adjusted data, 36.67 percent remained in the lowest decile, but the corresponding figure is 22.72 percent if the figures are unadjusted for age. We note that the primary difference in these comparisons was the distance moved. With unadjusted data, fewer moved out of the bottom decile, but in either case, little long-distance movement occurred. For example, the percent who moved from the bottom decile into the top five deciles was 11.88 in Table 3 and 10.02 percent in Table 4.

Table 5 gives average decile position for various subgroups of our sample in period 1 and period 2, including breakdowns by occupation, residence, schooling, marital status, ethnicity, age, and composition of assets in period $1 .{ }^{11}$ Only minor differences in patterns existed for the unadjusted and the age-adjusted data. The largest movements in average decile position were associated with changes in marital status. Those who were married in period 1 and single (through divorce or death of a spouse) in period 2 experienced large declines while those who became married showed large increases. Men who were single in both periods also declined while women single in both periods had the lowest average decile position. Professional and skilled occupations and those with more education advanced slightly while the farmers, the unskilled, and those with less education declined, which is

\footnotetext{
${ }^{10}$ The age range for household heads is $30-59$ in period 1 , and in 75 percent of the age cohorts there were at least 110 observations. The range of sample sizes by age of the head was from 58 to 295 .

${ }^{11}$ Sample sizes in Tables 5 and 6 may vary across categories because data are not available for all variables.
} 
TABLE 5

Average Decile Position by Time Period and Shorrocks Measure, Unadjusted and AdJUSTED FOR AGE

\begin{tabular}{|c|c|c|c|c|c|c|c|}
\hline & \multirow[b]{2}{*}{$\mathrm{N}$} & \multicolumn{3}{|c|}{ Age Adjusted } & \multicolumn{3}{|c|}{ Age Unadjusted } \\
\hline & & Period 1 & Period 2 & Shorrocks & Period 1 & Period 2 & Shorrocks \\
\hline $\begin{array}{l}\text { Sample } \\
\text { Occupation of head }\end{array}$ & 4,255 & 5.56 & 5.57 & 0.790 & 5.54 & 5.56 & 0.787 \\
\hline White-collar & 1,208 & 6.63 & 6.66 & 0.829 & 6.52 & 6.59 & 0.829 \\
\hline Skilled blue-collar & 1,625 & 5.24 & 5.26 & 0.800 & 5.24 & 5.28 & 0.800 \\
\hline Service & 303 & 4.45 & 4.53 & 0.844 & 4.48 & 4.53 & 0.797 \\
\hline Farmer & 196 & 7.68 & 7.36 & 0.831 & 7.89 & 7.45 & 0.798 \\
\hline Unskilled & 481 & 3.85 & 3.78 & 0.807 & 3.96 & 3.83 & 0.771 \\
\hline Not employed & 295 & 3.41 & 3.47 & 0.793 & 3.51 & 3.58 & 0.848 \\
\hline \multicolumn{8}{|l|}{ Residence } \\
\hline Non-South & 2,608 & 5.89 & 5.84 & 0.792 & 5.87 & 5.84 & 0.786 \\
\hline South & 1,646 & 4.82 & 4.95 & 0.794 & 4.80 & 4.93 & 0.796 \\
\hline \multicolumn{8}{|l|}{ Years of schooling } \\
\hline$<12$ & 2,432 & 4.78 & 4.74 & 0.774 & 4.91 & 4.83 & 0.769 \\
\hline 12 & 1,067 & 6.06 & 6.09 & 0.826 & 5.92 & 6.00 & 0.824 \\
\hline$>12$ & 662 & 6.96 & 7.06 & 0.850 & 6.74 & 6.93 & 0.826 \\
\hline \multicolumn{8}{|l|}{ Marital history } \\
\hline M, single both years & 210 & 3.82 & 3.35 & 0.784 & 4.13 & 3.58 & 0.796 \\
\hline $\mathrm{F}$, single both years & 386 & 3.07 & 3.03 & 0.886 & 2.78 & 2.93 & 0.853 \\
\hline Both years married & 3,066 & 5.99 & 6.09 & 0.789 & 5.98 & 6.09 & 0.799 \\
\hline $\mathrm{F}$, married-single & 267 & 5.27 & 3.88 & 0.857 & 4.94 & 3.77 & 0.865 \\
\hline $\mathrm{M}$, married-single & 171 & 4.86 & 4.37 & 0.837 & 5.22 & 4.57 & 0.788 \\
\hline $\mathrm{F}$, single-married & 99 & 3.88 & 5.99 & 0.951 & 3.47 & 5.48 & 0.911 \\
\hline $\mathrm{M}$, single-married & 49 & 3.52 & 4.10 & 0.941 & 3.93 & 4.38 & 0.581 \\
\hline \multicolumn{8}{|l|}{ Ethnicity } \\
\hline White & 2,887 & 5.84 & 5.86 & 0.798 & 5.81 & 5.84 & 0.797 \\
\hline Black & 1,315 & 2.97 & 2.83 & 0.844 & 3.05 & 2.91 & 0.852 \\
\hline Other & 53 & 5.47 & 5.66 & 0.791 & 5.58 & 5.72 & 0.788 \\
\hline \multicolumn{8}{|l|}{ Age of head } \\
\hline $30-39$ & 1,067 & & & & 4.70 & 5.02 & 0.827 \\
\hline $40-49$ & 1,773 & & & & 5.64 & 5.67 & 0.771 \\
\hline $50-59$ & 1,415 & & & & 6.06 & 5.84 & 0.801 \\
\hline \multicolumn{8}{|l|}{ Composition of assets } \\
\hline Owned home & 2,386 & 6.57 & 6.38 & 0.820 & 6.52 & 6.37 & 0.824 \\
\hline Did not own home & 1,869 & 3.89 & 4.21 & 0.830 & 3.92 & 4.22 & 0.830 \\
\hline
\end{tabular}

Source: NLS samples of older men in 1966 and 1976 and mature women in 1967 and 1977.

Note: Unless indicated otherwise, all variables refer to values taken in period 1.

consistent with evidence on the relatively high returns to education and experience in the 1960s and 1970s. ${ }^{12}$ Although the relative wage of new college graduates fell from the late 1960s through the mid 1970s (Freeman, 1977), our sample consists primarily of those with considerable experience, the returns to which increased during the period of our sample, particularly among the college-educated (Katz and Murphy, 1992). Southerners experienced modest gains in assets relative to residents of other regions, and whites improved their position slightly relative to blacks.

\footnotetext{
${ }^{12}$ White-collar workers consist of professional, technical and kindred workers (33.10 percent), managers, officials and proprietors (32.75 percent), clerical and kindred workers (22.54 percent) and sales workers (11.61 percent). Skilled blue-collar workers consist of craftsmen, foremen and kindred workers (48.55 percent) and operatives and kindred workers (51.45 percent). Unskilled workers consist of farm laborers (22.25 percent) and other laborers (77.75 percent).
} 
TABLE 6

Proportion Whose Decile Position Declined or Increased and Proportion who Remained at or Below Zero, Adjusted and Unadjusted for Age

\begin{tabular}{|c|c|c|c|c|c|c|}
\hline & \multirow[b]{2}{*}{$\mathrm{N}$} & \multicolumn{2}{|c|}{ Age Adjusted } & \multirow[b]{2}{*}{ at $\leq 0$} & \multicolumn{2}{|c|}{ Age Unadjusted } \\
\hline & & $\mathrm{Up} \geq 2$ & Down $\geq 2$ & & $\mathrm{Up} \geq 2$ & Down $\geq 2$ \\
\hline $\begin{array}{l}\text { Sample } \\
\text { Occupation of head }\end{array}$ & 4,255 & 0.177 & 0.175 & 0.056 & 0.179 & 0.167 \\
\hline White-collar & 1,208 & 0.199 & 0.197 & 0.010 & 0.202 & 0.169 \\
\hline Skilled blue-collar & 1,625 & 0.184 & 0.173 & 0.039 & 0.187 & 0.173 \\
\hline Service & 303 & 0.198 & 0.163 & 0.107 & 0.191 & 0.162 \\
\hline Farmer & 196 & 0.105 & 0.215 & 0.004 & 0.085 & 0.197 \\
\hline Unskilled & 481 & 0.125 & 0.142 & 0.141 & 0.132 & 0.155 \\
\hline Not employed & 295 & 0.139 & 0.107 & 0.274 & 0.130 & 0.134 \\
\hline \multicolumn{7}{|l|}{ Residence } \\
\hline Non-South & 2,608 & 0.170 & 0.181 & 0.040 & 0.177 & 0.175 \\
\hline South & 1,646 & 0.195 & 0.160 & 0.092 & 0.185 & 0.150 \\
\hline \multicolumn{7}{|l|}{ Years of schooling } \\
\hline$<12$ & 2,432 & 0.160 & 0.161 & 0.095 & 0.152 & 0.170 \\
\hline 12 & 1,067 & 0.187 & 0.203 & 0.017 & 0.196 & 0.181 \\
\hline$>12$ & 662 & 0.214 & 0.166 & 0.010 & 0.228 & 0.142 \\
\hline \multicolumn{7}{|l|}{ Marital history } \\
\hline $\mathrm{M}$, single both years & 2,887 & 0.181 & 0.177 & 0.035 & 0.185 & 0.169 \\
\hline $\mathrm{F}$, single both years & 1,315 & 0.129 & 0.155 & 0.246 & 0.108 & 0.145 \\
\hline $\begin{array}{l}\text { Both years married } \\
\text { F, married-single }\end{array}$ & 53 & 0.283 & 0.189 & 0.094 & 0.302 & 0.189 \\
\hline $\begin{array}{l}\mathrm{F} \text {, married-single } \\
\mathrm{M} \text {, married-single }\end{array}$ & 210 & 0.068 & 0.172 & 0.203 & 0.083 & 0.206 \\
\hline $\mathrm{F}$, single-married & 386 & 0.183 & 0.176 & 0.335 & 0.145 & 0.118 \\
\hline $\mathrm{M}$, single-married & 3,066 & 0.184 & 0.160 & 0.022 & 0.188 & 0.152 \\
\hline Ethnicity & 267 & 0.086 & 0.397 & 0.011 & 0.102 & 0.380 \\
\hline White & 171 & 0.116 & 0.241 & 0.149 & 0.081 & 0.298 \\
\hline Black & 99 & 0.490 & 0.069 & 0.000 & 0.561 & 0.054 \\
\hline Other & 49 & 0.231 & 0.081 & 0.218 & 0.195 & 0.106 \\
\hline \multicolumn{7}{|l|}{ Age of head } \\
\hline $30-39$ & 1,067 & & & 0.058 & 0.259 & 0.148 \\
\hline $40-49$ & 1,773 & & & 0.046 & 0.169 & 0.157 \\
\hline $50-59$ & 1,415 & & & 0.066 & 0.133 & 0.195 \\
\hline \multicolumn{7}{|l|}{ Composition of assets } \\
\hline Owned home & 2,386 & 0.156 & 0.207 & 0.001 & 0.156 & 0.207 \\
\hline Did not own home & 1,869 & 0.213 & 0.121 & 0.146 & 0.213 & 0.121 \\
\hline
\end{tabular}

Source: NLS samples of older men in 1966 and 1976, and mature women in 1967 and 1977.

Note: Unless indicated otherwise, all variables refer to values taken in period 1.

Although the stock market performed poorly during the late 1960s and the 1970s, housing prices increased considerably. ${ }^{13}$ Approximately 62.0 percent of the households in our sample owned a home in period 1, and the share of home equity as a portion of net worth (35.8 percent) in the sample was somewhat below that of 44 percent reported by the Survey of Consumer Finances in 1970 (Avery et al., 1984; table 6). ${ }^{14}$ Thus, one might expect homeowners to have advanced relative to households that did not own a home in period 1. Surprisingly, the average decile position of homeowners, while above that of non-homeowners, actually declined

\footnotetext{
${ }^{13}$ The New York Stock Exchange composite index increased 15.8 percent between 1966 and 1976 while the CPI index of housing costs rose 99 percent and the overall CPI increased 75.6 percent.

${ }^{14}$ In the SCF this is the value of home plus land minus home mortgages.
} 
slightly. Section 5 explores the connection between home ownership and mobility in more detail.

The Shorrocks (1978) measure of mobility focuses on those who remained in the same decile position. Defined as $\left(N-\operatorname{tr}\left(r_{i j}\right)\right) /(N-1)$ where $N$ is the size of the matrix and $r_{i j}$ denotes an element of the matrix expressed as a proportion of 1 , a number closer to 1.0 indicates greater mobility. The measure takes on a value of 0.0 if all households remained at the same decile position and equals 1.0 if the probabilities of movement to other deciles were equal regardless of starting position (all the diagonal elements of the transition matrix equaled 0.10 ).

According to the age-adjusted Shorrocks measures given in Table 5, the highest rate of mobility (0.951) occurred for females who married or who became single by period 2. Relatively high rates of mobility also existed for service workers, those with more than 12 years of schooling, and blacks. The least mobile included those with less than 12 years of schooling, men who were single in both periods, and individuals who were married both years.

The Shorrocks measures were similar for age-adjusted and age-unadjusted data with the exceptions of men who moved from single to married status and of women who moved from married to single status. However, the first - and possibly the second - exception may be an artifact of the small sample size.

By the Shorrocks criterion, households in our sample were less mobile than a Utah frontier group of the mid-1800s, in which the Shorrocks measure ranged from 0.874 to 0.936 (Kearl and Pope, 1984), but more mobile than a national sample of the same era in which the Shorrocks measure was 0.605 (Steckel, 1990).

Table 6 provides additional information on the mobility of various subgroups based on information in the off-diagonal elements of the transition matrix. The broad patterns described below hold for both age-adjusted and age-unadjusted data. The most upwardly groups, defined by the percentage who rose two or more deciles, included households headed by white-collar workers, those with more than 12 years of schooling, and especially individuals who were single in period 1 and married in period 2. ${ }^{15}$ Upward mobility improved with schooling and was greater among whites than blacks. Downward mobility was greatest among those who were married in period 1 and single in period 2. Approximately 5.6 percent of all households had zero or negative net family assets in both periods. The groups most likely to have remained at zero or negative wealth included those who remained single, the unemployed, blacks, men who were single in year 1 and married in year 2, and the unskilled. Additional calculations show that the most rapid movement out of the zero or negative wealth category occurred among professionals, households headed by older individuals, and people with more than 12 years of schooling.

Many investigations into mobility have asked whether "the rich got richer and the poor got poorer." For our contribution to this discussion we estimated the average relationship between net family assets in the two periods using a cubic functional form and OLS. The estimated regression equation is:

\footnotetext{
${ }^{15}$ White-collar workers also had a surprisingly high amount of downward mobility in the ageadjusted data, but this effect vanishes in the regression of movement into the lowest three deciles, discussed below. If white-collar workers declined at a high rate, apparently they did not move far.
} 
TABLE 7

Annual Growth Rates in Assets by Asset Level in Period 1

\begin{tabular}{cc}
\hline \hline Assets in Period 1 (\$) & Growth Rate $(\%)$ \\
\hline 5,000 & 9.65 \\
10,000 & 6.42 \\
15,000 & 5.03 \\
20,000 & 4.22 \\
30,000 & 3.29 \\
50,000 & 2.31 \\
75,000 & 1.57 \\
$100,000+$ & 1.00 \\
\hline
\end{tabular}

Source: Calculated from a regression on data from NLS samples of older men in 1966 and 1967, and mature women in 1967 and 1977.

$$
\mathrm{A} 2=7,154.1+1.203(\mathrm{~A} 1)-1.765 \times 10^{-6}(\mathrm{~A} 1)^{2}+7.670 \times 10^{-13}(\mathrm{~A} 1)^{3}
$$

$$
\text { (11.98) (42.16) (-12.193) }
$$

where $\mathrm{Ai}=$ net family assets in period $\mathrm{i}$ in 1967 dollars; $\mathrm{i}=1,2 ; \mathrm{R}^{2}=0.51$; and $\mathrm{N}=4,255$. $\mathrm{T}$-values are given in parentheses. On average all households were better off in period 2 compared with period 1 . The greatest absolute gains in wealth occurred for those who were wealthy in the first period, and in this sense the rich got richer. However, there was an inverse association between wealth in period 1 and the rate of growth of wealth between periods 1 and 2. Table 7 indicates that the wealth of households with an initial value of $\$ 5,000$ in net family assets grew at an annual rate of 9.65 percent up to period 2. Growth rates declined monotonically at higher levels of initial wealth, reaching 1.00 percent at $\$ 100,000$ of wealth in period 1. The declining pattern in rates of growth as a function of wealth was similar to that observed for the mid-nineteenth century (Steckel, 1990). The patterns in both time periods were probably influenced in part by life cycle phenomena. The young, who tended to be less wealthy, accumulated rapidly while older, wealthier individuals engaged in relatively more consumption. In addition, the young were more likely than the old to receive inheritances or inter vivos transfers. It is also possible that the middle class engaged in more aggressive investment strategies, which paid on average higher rates of return, while the rich tended to conserve wealth.

\section{Statistical Analysis}

The previous discussion identified several influences on mobility, and here we use regression analysis to clarify the independent role of these factors. Because activity near the extremes of the wealth distribution has always attracted special interest, our goal is to understand forces that led to persistence in the top or the bottom of the wealth distribution or to movement into the top or the bottom, which we define as deciles 8, 9, and 10 and 1, 2, and 3, respectively. We estimate four logit regressions for this purpose, whereby the dependent variable takes on a value of 1 if a household head persisted within the bottom (top) or moved into the 
bottom (top), and is 0 otherwise. ${ }^{16}$ At the end of this section we also present results of a regression on change in percentile position.

Although economists have yet to create a reasonably comprehensive theory of wealth (or income) mobility, our choice of regressors can be motivated by a combination of well-developed theories of aspects of wealth accumulation, and by prior studies and intuition. Of course, we are constrained in this process by the variables available in the NLS.

The relevance of age can be understood from the life-cycle model of savings proposed by Modigliani and Blumberg (1954) and modified by Tobin (1967) and others. Subsequent research showed the inadequacies of life-cycle factors alone, and various studies established the importance of earnings in explaining wealth ownership (White, 1978; Wolff, 1981). Therefore, we incorporate proxies for earnings that would follow from a human-capital model, including the head's years of schooling and occupation path.

Marital history influences household wealth through pooling of assets by marriage or division of assets by divorce. Moreover, divorce (or factors leading to it) might create psychological burdens that affect an individual's capacity for work and earnings. Family composition (number of dependants) affects wealth because dependants typically consume more than they earn. Variations in economic performance by region have occurred within the United States since the nineteenth century, and relevant for this study is that the southern economy performed well during the 1960s and 1970s. An earlier section of the paper briefly noted the relevance of asset composition for wealth accumulation. Finally, we include a variable for ethnicity on grounds that discrimination or other barriers to social mobility were likely to have affected the economic status of blacks.

Tables 8 and 9 present the results. Systematic differences in wealth mobility occurred by years of schooling, conjugal status, homeownership, occupation, ethnicity, number of dependants, and region of residence. The chances of persisting in the bottom and moving into the bottom declined by approximately 1.4 and 1.2 percentage points per year of schooling, respectively. One additional year of schooling increased the probability of persisting in the top by nearly 2 percentage points and increased the chances of moving into the top by 1.1 percentage points. The economic benefits of schooling during this era were moderated by considerable growth in the supply of well-educated workers as documented by Acemoglu (1998, 2002), Autor et al. (1998), and Katz and Autor (1999).

Conjugal status had a large impact on wealth mobility. Relative to those who remained married, greater chances of persisting in the bottom were faced by single men (20 percentage points) and by married women who became single (12 percentage points). Single women who married increased their probability of leaving the bottom deciles by 19 percentage points. Greater chances of moving into the bottom were faced by men who remained single (20 percentage points) and by married women who became single (14 percentage points). Married women who

\footnotetext{
${ }^{16} \mathrm{We}$ have also experimented with other approaches, using multinomial logit models of mobility (in which choices were to move up, move down, or stay in the same position), and the fundamental results are similar to those reported here.
} 
TABLE 8

Explaining Persistence in and Movement into the Bottom Three Deciles

\begin{tabular}{|c|c|c|c|c|c|c|c|c|}
\hline \multirow[b]{2}{*}{ Variable } & \multicolumn{4}{|c|}{ Persistence in Bottom } & \multicolumn{4}{|c|}{ Movement into Bottom } \\
\hline & Coeff. & t-value & $\partial \mathrm{P} / \partial \mathrm{X}$ & Mean & Coeff. & t-value & $\partial \mathrm{P} / \partial \mathrm{X}$ & Mean \\
\hline Constant & 0.9806 & 1.46 & 0.1301 & & -0.8709 & -1.34 & -0.0910 & \\
\hline Age of head & 0.0065 & 0.53 & 0.0009 & 44.50 & 0.0014 & 0.13 & 0.0001 & 46.30 \\
\hline Years of school & -0.1061 & -4.29 & -0.0141 & 8.27 & -0.1152 & -5.22 & -0.0120 & 10.77 \\
\hline No. of dependants & 0.1339 & 3.80 & 0.0178 & 2.51 & 0.0817 & 2.40 & 0.0085 & 2.07 \\
\hline Owned home & -1.0945 & -6.65 & -0.1453 & 0.179 & -0.7959 & -5.06 & -0.0832 & 0.812 \\
\hline \multicolumn{9}{|l|}{ Occup. history } \\
\hline WC-WC & -0.2289 & -0.84 & -0.0304 & 0.091 & -0.2953 & -1.29 & -0.0309 & 0.247 \\
\hline Serv-Serv & -0.4382 & -1.14 & -0.0582 & 0.037 & 0.4983 & 1.29 & 0.0521 & 0.020 \\
\hline Farm-Farm & -0.7647 & -0.97 & -0.1015 & 0.005 & -1.9123 & -3.36 & -0.1998 & 0.032 \\
\hline Unsk-Unsk & 0.2153 & 0.60 & 0.0286 & 0.050 & 0.4829 & 1.27 & 0.0505 & 0.019 \\
\hline Unemp-Unemp & 0.4920 & 1.47 & 0.0653 & 0.092 & 0.0674 & 0.17 & 0.0070 & 0.021 \\
\hline Leave WC & 0.0511 & 0.17 & 0.0068 & 0.054 & -0.0200 & -0.08 & -0.0021 & 0.138 \\
\hline Into WC & -0.8438 & -2.88 & -0.1120 & 0.056 & 0.2796 & 1.06 & 0.0292 & 0.071 \\
\hline Leave BC & 0.3382 & 1.46 & 0.0449 & 0.172 & 0.3879 & 1.84 & 0.0405 & 0.138 \\
\hline Into $\mathrm{BC}$ & 0.7105 & 2.16 & 0.0943 & 0.069 & 0.6845 & 2.15 & 0.0715 & 0.030 \\
\hline Other & 1.0111 & 3.70 & 0.1342 & 0.204 & 0.2188 & 0.88 & 0.0229 & 0.068 \\
\hline \multicolumn{9}{|l|}{ Ethnicity } \\
\hline Black & 0.7814 & 4.97 & 0.1037 & 0.550 & 0.9657 & 5.91 & 0.1009 & 0.151 \\
\hline Other & -0.8131 & -0.97 & -0.1079 & 0.006 & -0.0518 & -0.11 & -0.0054 & 0.016 \\
\hline \multicolumn{9}{|l|}{ Marital history } \\
\hline Single-Single (M) & 1.4844 & 4.16 & 0.1970 & 0.277 & 1.8824 & 6.83 & 0.1967 & 0.052 \\
\hline Single-Single (F) & 0.2205 & 0.51 & 0.0293 & 0.195 & -0.1900 & -0.45 & -0.0199 & 0.022 \\
\hline Married-Single (M) & 0.9056 & 2.30 & 0.1202 & 0.123 & 1.3390 & 5.02 & 0.1399 & 0.083 \\
\hline Married-Single (F) & -0.1255 & -0.25 & -0.0167 & 0.069 & 0.6384 & 1.88 & 0.0667 & 0.049 \\
\hline Single-Married (M) & 0.4617 & 0.85 & 0.0613 & 0.064 & 0.6299 & 1.10 & 0.0658 & 0.017 \\
\hline Single-Married (F) & -1.4019 & -2.26 & -0.1860 & 0.044 & -0.7307 & -0.82 & -0.0764 & 0.010 \\
\hline \multicolumn{9}{|l|}{ Region } \\
\hline South-South & -0.1419 & -0.91 & -0.0188 & 0.501 & 0.1197 & 0.81 & 0.0125 & 0.287 \\
\hline South-Non-South & -1.0910 & -2.07 & -0.1448 & 0.016 & 2.2075 & 4.22 & 0.2307 & 0.008 \\
\hline Non-South-South & -0.1598 & -0.34 & -0.0212 & 0.018 & 0.3860 & 0.92 & 0.0403 & 0.021 \\
\hline Mean of Dep Var & \multicolumn{4}{|c|}{0.772} & \multicolumn{4}{|c|}{0.154} \\
\hline Sample Size & \multicolumn{4}{|c|}{1,586} & \multicolumn{4}{|c|}{2,482} \\
\hline$\%$ Correct Pred & \multicolumn{4}{|c|}{0.814} & \multicolumn{4}{|c|}{0.859} \\
\hline$-2 \log \lambda$ & \multicolumn{4}{|c|}{-658.2} & \multicolumn{4}{|c|}{-863.0} \\
\hline
\end{tabular}

Source: NLS samples of older men in 1966 and 1976, and mature women in 1967 and 1977.

Note: The dependent variable (equation 1) $=1$ if the household was in the bottom three deciles in both periods and $=0$ if the household was in the bottom three deciles in period 1 but not period 2 . The dependent variable (equation 2) $=1$ if the household was in the bottom 3 deciles in period 2 but not period 1 , and $=0$ if the household was not in the bottom three deciles in either period. The omitted category refers to a white worker who, in both periods, was blue-collar, married and lived in outside the South.

became single suffered the largest reduction in the probability of persisting in the top deciles (21 percentage points). Higher chances of leaving the top were faced by married men who became single ( 9 percentage points) and by men who remained single (7 percentage points).

Relative to non-owners, those who owned homes in period 1 had lower chances of remaining in the bottom (15 percentage points) and of moving into the bottom (8 percentage points). Although home ownership had no systematic effect 
TABLE 9

Explaining Persistence in and Movement into the Top Three Deciles

\begin{tabular}{|c|c|c|c|c|c|c|c|c|}
\hline \multirow[b]{2}{*}{ Variable } & \multicolumn{4}{|c|}{ Persistence in Top } & \multicolumn{4}{|c|}{ Movement into Top } \\
\hline & Coeff. & t-value & $\partial \mathrm{P} / \partial \mathrm{X}$ & Mean & Coeff. & t-value & $\partial \mathrm{P} / \partial \mathrm{X}$ & Mean \\
\hline Constant & -3.5312 & -4.28 & -0.6453 & & -4.3286 & -6.52 & -0.3113 & \\
\hline Age of head & 0.0620 & 4.57 & 0.0113 & 48.02 & 0.0069 & 0.62 & 0.0005 & 44.82 \\
\hline Years of school & 0.1072 & 3.64 & 0.0196 & 11.61 & 0.1617 & 6.22 & 0.0116 & 9.21 \\
\hline No. of dependants & 0.0090 & 0.17 & 0.0016 & 1.77 & -0.1059 & -2.48 & -0.0076 & 2.40 \\
\hline Owned home & 0.1827 & 0.84 & 0.0334 & 0.777 & 0.6965 & 4.19 & 0.0501 & 0.497 \\
\hline \multicolumn{9}{|l|}{ Occup. history } \\
\hline $\mathrm{WC}-\mathrm{WC}$ & 0.3130 & 1.26 & 0.0572 & 0.299 & 0.5827 & 2.74 & 0.0419 & 0.150 \\
\hline Serv-Serv & -0.3003 & -0.50 & -0.0549 & 0.014 & -0.3670 & -0.59 & -0.0264 & 0.031 \\
\hline Farm-Farm & 1.8894 & 3.75 & 0.3453 & 0.068 & 2.5877 & 4.53 & 0.1861 & 0.007 \\
\hline Unsk-Unsk & -0.9411 & -1.16 & -0.1720 & 0.008 & 0.1663 & 0.30 & 0.0120 & 0.0390 \\
\hline Unemp-Unemp & -1.0264 & -1.91 & -0.1876 & 0.016 & -1.0418 & -1.38 & -0.0749 & 0.059 \\
\hline Leave WC & -0.0515 & -0.20 & -0.0094 & 0.186 & 0.3113 & 1.22 & 0.0224 & 0.079 \\
\hline Into WC & 0.8301 & 2.13 & 0.1517 & 0.057 & 0.5591 & 2.10 & 0.0402 & 0.068 \\
\hline Leave BC & -0.1096 & -0.39 & -0.0200 & 0.116 & 0.3215 & 1.33 & 0.0231 & 0.162 \\
\hline Into $\mathrm{BC}$ & -0.5452 & -1.03 & -0.0996 & 0.021 & -0.7114 & -1.42 & -0.0512 & 0.053 \\
\hline Other & 0.2235 & 0.60 & 0.0408 & 0.063 & -0.4397 & -1.17 & -0.0316 & 0.140 \\
\hline \multicolumn{9}{|l|}{ Ethnicity } \\
\hline Black & -1.2909 & -3.67 & -0.2359 & 0.047 & -1.3002 & -5.35 & -0.0935 & 0.390 \\
\hline Other & 0.0541 & 0.09 & 0.0099 & 0.014 & 1.2797 & 2.91 & 0.0920 & 0.011 \\
\hline \multicolumn{9}{|l|}{ Marital history } \\
\hline Single-Single (M) & -0.4429 & -0.87 & -0.0809 & 0.034 & -1.0168 & -2.10 & -0.0731 & 0.174 \\
\hline Single-Single (F) & -0.3962 & -0.47 & -0.0724 & 0.011 & -0.5638 & -0.84 & -0.0405 & 0.115 \\
\hline $\begin{array}{l}\text { Married-Single } \\
\text { (M) }\end{array}$ & -0.2264 & -0.53 & -0.0414 & 0.063 & -1.2963 & -2.13 & -0.0932 & 0.110 \\
\hline Married-Single (F) & -1.1466 & -1.93 & -0.2096 & 0.028 & 0.3684 & 0.53 & 0.0265 & 0.066 \\
\hline $\begin{array}{l}\text { Single-Married } \\
\text { (M) }\end{array}$ & 2.2116 & 1.10 & 0.4042 & 0.012 & 0.5505 & 0.95 & 0.0396 & 0.043 \\
\hline Single-Married (F) & a & & & & 0.6696 & 1.01 & 0.0482 & 0.029 \\
\hline \multicolumn{9}{|l|}{ Region } \\
\hline South-South & 0.1655 & 0.84 & 0.0302 & 0.208 & -0.0176 & -0.11 & -0.0013 & 0.423 \\
\hline South-Non-South & -1.6674 & -1.97 & -0.3047 & 0.009 & -1.6285 & -1.55 & -0.1171 & 0.012 \\
\hline Non-South-South & -0.4021 & -0.86 & -0.0735 & 0.021 & 0.1946 & 0.47 & 0.0140 & 0.019 \\
\hline Mean of Dep Var & \multicolumn{4}{|c|}{0.702} & \multicolumn{4}{|c|}{0.091} \\
\hline Sample Size & \multicolumn{4}{|c|}{990} & \multicolumn{4}{|c|}{3,078} \\
\hline$\%$ Correct Pred & \multicolumn{4}{|c|}{0.728} & \multicolumn{4}{|c|}{0.909} \\
\hline$-2 \log \lambda$ & \multicolumn{4}{|c|}{-540.0} & \multicolumn{4}{|c|}{-755.7} \\
\hline
\end{tabular}

Source: NLS samples of older men in 1966 and 1976, and mature women in 1967 and 1977.

Note: The dependent variable (equation 1) $=1$ if the household was in the top three deciles in both periods and $=0$ if the household was in the top three deciles in period 1 but not period 2 . The dependent variable (equation 2) $=1$ if the household was in the top three deciles in period 2 but not period 1 , and $=0$ if the household was not in the top 3 deciles in either period. The omitted category refers to a white worker who, in both periods, was blue-collar, married, and lived outside the South.

${ }^{\mathrm{a}}$ Too few cases for study.

on persistence in the top 3 deciles, it did increase the chances of moving into the top by 5 percentage points. ${ }^{17}$

${ }^{17}$ The justification for taking home ownership as exogenous are that: (a) the decision to own or not to own a home had been made by the beginning of the period in which we study mobility; (b) important changes in property values occurred during the decade of the study; and (c) property formed a large share of most wealth portfolios. In principle, one could model the decision to own a home, which would require values of explanatory variables prior to period 1 . However, these variables are unavailable. 
Farmers benefited from the rise of land prices in the 1970s. Compared with the omitted class (workers who were blue-collar in both periods), this group was less likely to move into the bottom by 20 percentage points, more likely to persist in the top (35 percentage points) and more likely (19 percentage points) to move into the top. Other occupations that faired well included white-collar workers, who were more likely (by 5 percentage points) to move into the top, and those who moved into white-collar work, who were more likely (15 percentage points) to persist in the top or to move into the top (4 percentage points). Those who moved into blue-collar work declined relative to those who remained in that line of employment.

Others things equal, blacks did not fare as well as whites in the 1960s and 1970s. Relative to whites, blacks were more likely by 10 percentage points to persist and to move into the bottom three deciles. Of all socioeconomic groups studied, blacks faced the largest risk of leaving the top ( 24 percentage points). They were also 9 percentage points less likely than whites to move into the top.

Dependants deterred upward mobility and promoted downward mobility. The chances of persistence in the bottom increased by 1.8 percentage points per dependant, and an additional dependant increased the probability of moving into the bottom by 0.9 percentage points. The chances of moving into the top declined by 0.8 percentage points per dependant.

In the category of region of residence, those who left the South were adversely affected. Compared with households that remained outside the South, those who left the South were more likely to persist in the bottom (by 14 percentage points), to move into the bottom (by 23 percentage points), and less likely to persist in the top (by 30 percentage points). We do not have a convincing explanation for this phenomenon, but it is well-known that southerners were poorly integrated into national labor markets during the nineteenth century, avoiding moves to the North that would have doubled their wages. Perhaps clashes of culture and levels of education were involved and these lingered well into the twentieth century, such that those who left the South as late as the 1960s faced challenges in adapting to living and employment in other regions. It is also possible that unmeasured characteristics of southerners, such as levels of skill or training within a given occupation, adversely affected outcomes. These conjectures warrant further investigation.

Surprisingly, age was not systematically related to persistence or mobility into the bottom or to movement into the top. This result holds whether a linear or a quadratic functional form is used. ${ }^{18}$ However, if other things are held constant, the chances of persisting in the top increase with age. Someone aged 55 had a 28 percentage point greater probability of remaining in the top compared with someone aged 30 .

While useful, the marginal effects discussed above do not tell the full story of diversity of opportunity in American society because some groups faced a combi-

\footnotetext{
${ }^{18} \mathrm{We}$ also estimated logit regressions that included a squared term in age of the household head, but the results were similar in that the age coefficients were jointly insignificant with the exception of the equation on remaining in the top three deciles. In that regression the probability of remaining in the top peaked when the household head was age 51.6 in period 1, and the expected probability of remaining in the top was 47.5 percent at age $35,74.4$ percent at age 45 and 77.3 percent at age 55 .
} 
nation of several favorable or unfavorable circumstances. Thus, particular individuals may have faced far greater chances of upward or downward mobility than the marginal effects alone would indicate. As a general tendency, upward mobility was less (and downward mobility was greater) among the less educated, blacks, those who remained single, and those who did not own homes.

We address this situation calculating expected probabilities of persistence or movement for various subgroups of the population. Table 10 shows the expected probabilities for various groups who were particularly advantaged or disadvantaged. For example, the first row shows that the chances of remaining in the bottom three deciles was 98.1 percent for a household headed by a black woman who became single, had five dependants, and who did not own a home, had eight years of schooling and moved into blue-collar work. Such a household moved to the bottom with a probability of 92.0 percent, persisted at the top with a probability of 6.7 percent and moved to the top with a probability of 0.2 percent. In contrast, the chances of persistence in the bottom were 19.3 percent for a household headed by a married, white male with 16 years of schooling and who had one dependant, owned a home and was a farmer in both periods. This type of household moved to the bottom with probability of 0.7 percent, persisted at the top with probability of 96.5 percent, and moved to the top with probability of 80.8 percent. The table gives probabilities for other types of households, and readers may calculate additional expected probabilities using the sample means and coefficients given in Tables 8 and 9.

For comparative purposes we also estimated a regression of a household's change in percentile position on the same variables as used in the logit models (Table 11). In this regression it is important to control also for the initial starting percentile. The fundamental results are similar to those for the logits. Upward mobility was associated with age and years of schooling, and among the occupations the winners included white-collar workers and farmers while those who fell behind were blue-collar. Blacks lost ground as did those who remained single or became single, and those who left the South.

\section{IMPLICATIONS}

Our findings have several implications for the study of wealth distributions, poverty, and inequality. One is that cross-section measures of inequality, which are widely reported and discussed, may disguise significant underlying rates of mobility. The off diagonal elements of our transitions matrices show that a large share of households moved within the wealth distribution from the mid 1960s to the mid 1970s. Over two-thirds of the households moved one or more deciles and over one-third moved two or more deciles over a ten year interval. To the extent that mobility exists, cross-section measures overstate the degree of inequality in command over resources that households experience over time.

Researchers who are studying long-term trends or cross-section patterns of household wealth mobility should recognize the importance of marital history for movements within the distribution. Individuals who remained single and people whose marriages were terminated did significantly less well than those who remained married. The importance of family structure for wealth mobility is 


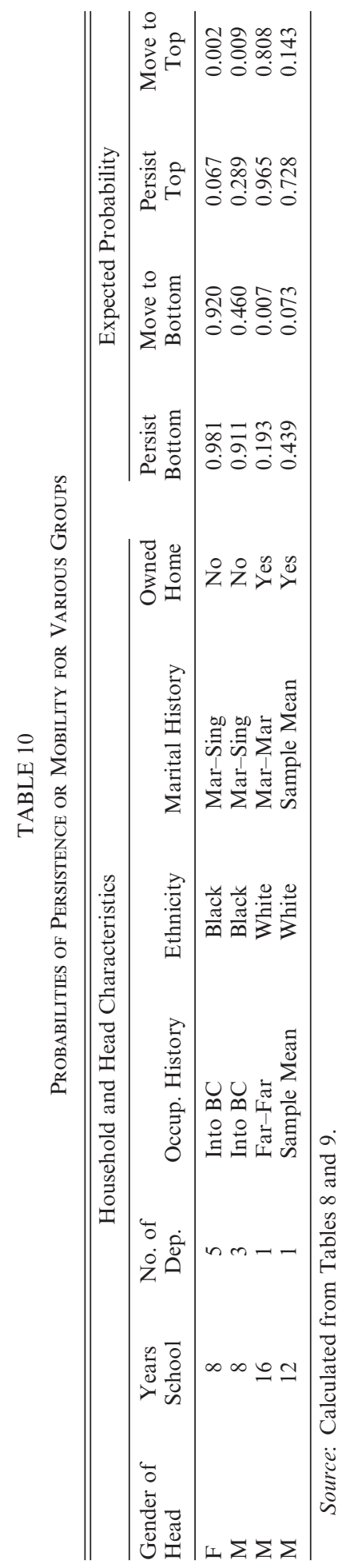


TABLE 11

Explaining the Change in Percentile Position

\begin{tabular}{|c|c|c|}
\hline Variable & Coeff. & t-value \\
\hline Constant & 12.4227 & 4.94 \\
\hline Age of head & 0.0116 & 0.25 \\
\hline Percentile 1 & -0.3947 & -31.10 \\
\hline Years of school & 0.7581 & 8.23 \\
\hline No. of dependants & -0.3385 & -2.50 \\
\hline Owned home & 1.2703 & 1.90 \\
\hline \multicolumn{3}{|l|}{ Occup. history } \\
\hline WC-WC & 4.0950 & 4.49 \\
\hline Serv-Serv & 1.2686 & 0.74 \\
\hline Farm-Farm & 15.2171 & 7.68 \\
\hline Unsk-Unsk & -2.9995 & -1.87 \\
\hline Unemp-Unemp & -0.9795 & -0.70 \\
\hline Leave WC & 0.4627 & 0.45 \\
\hline Into WC & 3.8592 & 3.25 \\
\hline Leave $\mathrm{BC}$ & -0.4750 & -0.52 \\
\hline Into $\mathrm{BC}$ & -3.2438 & -2.37 \\
\hline Other & -1.8647 & -1.84 \\
\hline \multicolumn{3}{|l|}{ Ethnicity } \\
\hline Black & -6.7150 & -9.52 \\
\hline Other & 1.4311 & 0.60 \\
\hline \multicolumn{3}{|l|}{ Marital history } \\
\hline Single-Single (M) & -10.3880 & -8.28 \\
\hline Single-Single (F) & 0.7891 & 0.50 \\
\hline Married-Single (M) & -7.4399 & -5.61 \\
\hline Married-Single (F) & -9.0205 & -5.23 \\
\hline Single-Married (M) & 0.9135 & 0.38 \\
\hline Single-Married (F) & 10.0139 & 3.38 \\
\hline \multicolumn{3}{|l|}{ Region } \\
\hline South-South & 1.1137 & 1.85 \\
\hline South-Non-South & -5.0664 & -2.08 \\
\hline Non-South-South & -2.4040 & -1.28 \\
\hline
\end{tabular}

Source: NLS samples of older men in 1966 and 1976, and mature women in 1967 and 1977.

Note: The omitted category refers to a white worker who, in both periods, was blue-collar, married, and lived outside the South.

consistent with results for income mobility from the PSID for the period 1971 to 1978 (Duncan, 1984). Therefore researchers who want to measure the effects of economic processes on mobility should understand that demographic changes or differences, such as a higher age at marriage or growing divorce rates, may have important effects on observed mobility rates.

Our research helps tie interest in the course of relative wages to questions of poverty, inequality, and mobility. Recently scholars have charted patterns and sought explanations for trends in the wage structure over the past several decades. According to Goldin and Margo (1992), wage dispersion was at a minimum around 1950 and increased steadily thereafter, particularly after 1970. Katz and Murphy (1992) maintain that changes in within-sector demand for labor and relative changes in the growth rate of skilled and unskilled labor were driving forces while Bound and Johnson (1992) emphasize the consequences of biased technological change on the demand for various skill classes of labor. Because wages are only one component of earnings or wealth, it is important to link 
changes in the pattern of wages to broader measures of economic well-being. Our research confirms that returns to experience during the 1960s and 1970s was accompanied by patterns of mobility that led to relatively rapid wealth accumulation by workers who were well-educated or skilled. In contrast, data from the PSID indicate that skills and training had little influence on income mobility for the period 1971 to 1978 (Duncan, 1984).

Comparisons with a similar study for the mid-nineteenth century (Steckel, 1990) suggest that some important changes in mobility patterns have occurred. Slightly over a century earlier, the ten-year persistence rate in the lowest four deciles was 60 percent versus 76 percent in the NLS data (whether unadjusted or age-adjusted). In addition, in the nineteenth century persistence in the highest decile was lower (46 percent versus 62 percent in the unadjusted and 58 percent in the age-adjusted data). Mobility in the two studies was about the same as measured by the share who moved two deciles or more (39 percent versus 35 percent in the NLS), but a larger share remained at zero or negative wealth in the midnineteenth century (20 percent versus about 6 percent in the NLS). Although study of these contrasting patterns is just beginning, it is our hunch that the greater rigidity in the modern data at the extremes of the wealth distribution may have something to do with the growing importance of human capital to earnings and to wealth accumulation. The past century witnessed considerable growth in professional and skilled workers, such as physicians, lawyers, accountants, and engineers, who usually have high incomes and low unemployment ratescharacteristics that allow them to become wealthy and to persist near the top. Perhaps more individuals in the nineteenth century, were able to escape the lower end of the wealth distribution through a widely-played type of lottery: luck in purchasing land that became valuable through urbanization or the westward movement.

\section{Conclusions and Suggestions for Research}

Cross-section measures of poverty and inequality are widely used to document the distribution of economic rewards in the United States. We use data from the National Longitudinal Surveys (NLS) of older men and of mature women on net family assets collected over a ten year period to place cross-section measures in perspective. We find that households moved significantly within the wealth distributions between the mid 1960s and the mid 1970s. Those who fell behind included single people, blacks, individuals whose marriages were disrupted by divorce or death of a spouse, households with more dependants, and those who left the South. The gainers consisted of farmers and those with skilled jobs or high levels of education.

While our results suggest that systematic factors such as ethnicity, marital status, and education are associated with wealth mobility, we did not examine the role of random factors, external to the household or individual comment that could also influence such mobility. For example, future research can examine the question of the degree to which returns on financial investments that may have a large random component, such as stocks and bonds, are associated with wealth mobility. The answer could be relevant for policy; to the extent that random 
factors external to the individual or household are important, policies that operate on personal traits will be less effective in fostering upward mobility.

\section{APPENDIX}

Longitudinal surveys usually face the problem of non-response. Households interviewed in period 1 sometimes could not be found in a later period, and if they were located, some of these might not have agreed to an interview, and among these some may not have answered specific questions. Here we consider nonresponse to the wealth question in period 2, given the household provided wealth information in period 1 . Because household heads who died cannot be included in a study of mobility, we delete these cases and consider only households that did not respond for other reasons (including unknown).

If the wealthy of period 1 were less locatable or were more likely to refuse in period 2, then measured mobility is biased downward to the extent that wealth in both periods is positively correlated. On the other hand, the opposite bias would occur if the poor were more likely to drop out. In appraising selectivity over time we also consider the effect of other variables found relevant for mobility.

Table A1 shows estimates of a logit regression of failure to respond (to the wealth question in period 2) on period 1 values of wealth, age, ethnicity, number of dependants, and schooling. Non-response was not systematically related to wealth in period 1, a pattern also found in a univariate regression on wealth in period $1(\mathrm{z}=1.67)$. The coefficients on period 1 values of wealth and wealth squared were jointly insignificant in a regression on these two variables. In any event the estimated value of $\mathrm{dy} / \mathrm{dx}$ for wealth in period $1(0.0001729$ per thousand dollars) is small; an increase of two standard deviations (s.d. $=\$ 44,380$ ), which would move a household from the first to the tenth decile, increases the probability of non-response by only 1.53 percentage points.

Other variables did systematically affect non-response. The young, those with few dependants, the better educated, and "other" ethnicities (principally Hispanics) were less likely to answer. The values of $d y / d x$ show that the effects were important in a practical sense with young, poorly educated individuals of "other"

TABLE A1

Explaining Non-Response in Period 2

\begin{tabular}{lcrc}
\hline \hline Variable & Coefficient & \multicolumn{1}{c}{$\mathrm{z}$} & \multicolumn{1}{c}{$\mathrm{dy} / \mathrm{dx}$} \\
\hline Wealth in period 1 (000) & 0.0007142 & 1.25 & 0.0001729 \\
Age of head & -0.02258 & -6.75 & -0.00547 \\
Black & -0.09439 & -1.56 & -0.02276 \\
Other ethnicity & 0.40383 & 2.15 & 0.09994 \\
Number of dependants & -0.07789 & -5.68 & -0.01886 \\
Highest grade completed & 0.04150 & 5.19 & 0.01005 \\
Constant & 0.40051 & 1.98 & \\
Mean of Dep Var & 0.41295 & & \\
Sample size & 6,824 & & \\
-2 log $\lambda$ & 132.91 & & \\
\hline
\end{tabular}

Source: NLS samples of older men in 1966 and 1976, and of mature women in 1967 and 1977. 
ethnicity and few dependants less likely to remain in the survey from period 1 to period 2 (during its first decade). Non-response rates were higher for blacks and other ethnicities, but we do adjust for sample/population differences in the proportion of these groups in each year.

\section{REFERENCES}

Acemoglu, Daron, "Why Do New Technologies Complement Skills? Directed Technical Change and Wage Inequality," Quarterly Journal of Economics, 113(4), 1055-89, November 1998.

- "Technological Change, Inequality, and the Labor Market," Journal of Economic Literature, 40(1), 7-72, March 2002.

Autor, David H., Lawrence F. Katz, and Alan B. Kruger, "Computing Inequality: Have Computers Changed the Labor Market?" Quarterly Journal of Economics, 113(4), 1169-89, November 1998.

Avery, Robert B., Gregory E. Elliehausen, Glenn B. Canner, and Thomas A. Gustafson, "Survey of Consumer Finances, 1983: A Second Report," Federal Reserve Bulletin, 70(12), 857-68, December 1984.

Blackburn, McKinley L., David E. Bloom, and Richard B. Freeman, "An Era of Falling Earnings and Rising Inequality?” Brookings Review, 9, 38-43, Winter 1990/1991.

Bound, John and George Johnson, "Changes in the Structure of Wages in the 1980s: An Evaluation of Alternative Explanations," American Economic Review, 82(3), 371-92, June 1992.

Bureau of Labor Statistics, Employment and Earnings, 25, December 1978.

Card, David and Thomas Lemieux, "Can Falling Supply Explain the Rising Return to College for Younger Men? A Cohort-Based Analysis," Quarterly Journal of Economics, 116(2), 705-46, May 2001.

Center for Human Resource Research, NLS Handbook, 1991, Ohio State University, Columbus, 1991.

Duncan, Greg J., Years of Poverty, Years of Plenty: The Changing Economic Fortunes of American Workers and Families, Institute for Social Research, Ann Arbor, 1984.

Duncan, Greg J. and Saul D. Hoffman, "Dynamics of Wage Change," in Martha S. Hill, Daniel H. Hill, and James N. Morgan (eds), Five Thousand American Families-Patterns of Economic Progress, Vol. IX, Institute for Social Research, Ann Arbor, 45-92, 1981.

Feldstein, Martin S., "Social Security and the Distribution of Wealth," Journal of the American Statistical Association, 71(356), 800-7, December 1976.

Freeman, R. B., "The Decline in Economic Rewards to College Education," Review of Economics and Statistics, 59(1), 18-29, February 1977.

Goldin, Claudia and Lawrence F. Katz, "The Origins of Technology-Skill Complementarity," Quarterly Journal of Economics, 113(3), 693-732, August 1998.

Goldin, Claudia and Robert A. Margo, "The Great Compression: The Wage Structure in the United States at Mid-Century," Quarterly Journal of Economics, 107(1), 1-34, February 1992.

Grant, E. Kenneth and John Vanderkamp, "The Effects of Migration on Income: A Micro Study with Canadian Data, 1965-71," Canadian Journal of Economics, 13(3), 381-406, August 1980.

Hanratty, Maria J. and Rebecca M. Blank, "Down and Out in North America: Recent Trends in Poverty Rates in the United States and Canada," Quarterly Journal of Economics, 107(1), 233-54, February 1992.

Herscovici, Steven, "Migration and Economic Mobility: Wealth Accumulation and Occupational Change among Antebellum Migrants and Persisters," Journal of Economic History, 58(4), 927-56, December 1998.

Heston, Alan, Robert Summers, and Bettina Aten, Penn World Table Version 6.1, Center for International Comparisons at the University of Pennsylvania, CICUP, October 2002.

Jianakoplos, Nancy A. and Vickie L. Bajtelsmit, "Dual Private Pension Households and the Distribution of the Wealth in the United States," Journal of Pensions Economics and Finance, 1(2), 131-55, July 2002.

Jianakoplos, Nancy A. and Paul L. Menchik, "Wealth Mobility," Review of Economics and Statistics, 79(1), 18-31, February 1997.

Jianakoplos, Nancy A., Paul L. Menchik, and F. Owen Irvine, "Using Panel Data to Assess the Bias in Cross-sectional Inferences of Life-Cycle Changes in the Level and Composition of Household Wealth," in Robert E. Lipsey and Helen Stone Tice (eds), The Measurement of Saving, Investment, and Wealth, University of Chicago Press, Chicago, 553-640, 1989.

Jencks, Christopher, Rethinking Social Policy: Race, Poverty, and the Underclass, Harvard University Press, Cambridge, 1992. 
Katz, Lawrence F. and David H. Autor, "Changes in the Wage Structure and Earnings Inequality," in Orley Ashenfelter and David Card (eds), Handbook of Labor Economics, Vol. 3, Elsevier, New York, 1463-555, 1999.

Katz, Lawrence F. and Kevin M. Murphy, "Changes in Relative Wages, 1963-1987: Supply and Demand Factors," Quarterly Journal of Economics, 107(1), 35-78, February 1992.

Kearl, James R. and Clayne L. Pope, "Mobility and Distribution," Review of Economics and Statistics, 66(2), 192-9, May 1984.

Modigliani, Franco and Richard Blumberg, "Utility Analysis and the Consumption Function: An Interpretation of Cross-Section Data," in Kenneth K. Kurihara (ed.), Post Keynesian Economics, Rutgers University Press, New Brunswick, NJ, 388-436, 1954.

Murray, Charles, Losing Ground: American Social Policy, 1950-1980, Basic Books, New York, 1984.

Piketty, Thomas and Emmanuel Saez, "Income Inequality in the United States, 1913-1998," Quarterly Journal of Economics, 118(1), 1-39, February 2003.

Shorrocks, A. F., "Income Stability in the United States," in N. Anders Klevmarken and Johan A. Lybeck (eds), The Statics and Dynamics of Income, Tieto Ltd, Clevedon, UK, 175-94, 1981. , "The Measurement of Mobility," Econometrica, 46(5), 111-20, September 1978.

- "The Age-Wealth Relationship: A Cross-Section and Cohort Analysis," Review of Economics and Statistics, 57(2), 155-63, May 1975.

Smith, James D., "Trends in the Concentration of Personal Wealth in the United States, 1958 to 1976," Review of Income and Wealth, 30(4), 419-28, December 1984.

Steckel, Richard H., "Poverty and Prosperity: A Longitudinal Study of Wealth Accumulation, 18501860," Review of Economics and Statistics, 72(2), 275-85, May 1990.

_ , "The Economic Foundations of East-West Migration during the Nineteenth Century," Explorations in Economic History, 20(1), 14-36, January 1983.

Tobin, James, "Life Cycle Saving and Balanced Growth," in William Fellner et al. (eds), Ten Economic Studies in the Tradition of Irving Fisher, John Wiley, New York, 231-56, 1967.

U.S. Bureau of the Census, Historical Statistics of the United States, Colonial Times to 1970, USGPO, Washington, DC, 1975.

Welch, Finis (ed.), The Causes and Consequences of Increasing Inequality, University of Chicago Press, Chicago, 2001.

White, Betsy Buttrill, "Empirical Tests of the Life-Cycle Hypothesis," American Economic Review, 74(1), 547-60, September 1978.

Wilson, William Julius, The Truly Disadvantaged: The Inner City, the Underclass, and Public Policy, University of Chicago Press, Chicago, 1987.

Wolff, Edward N., "Changing Inequality of Wealth," American Economic Review, 82(2), 552-8, May 1992.

-, "The Accumulation of Household Wealth over the Life-Cycle: A Microdata Analysis," Review of Income and Wealth, 27(1), 75-96, March 1981.

Wolff, Edward N. and Marcia Marley, "Long-Term Trends in U.S. Wealth Inequality: Methodological Issues and Results," In Robert E. Lipsey and Helen Stone Tice (eds), The Measurement of Saving, Investment, and Wealth, University of Chicago Press, Chicago, 765-844, 1989. 